\section{Historic Haunts of England}

By Gwen Woodeock. Pp. xiii $+368+48$ plates. (London: Alexander Maclehose and Co., 1938.) $78,6 d$. net.

$\mathrm{IN}^{\mathrm{N}}$ the phrasing of a bygone age, Mrs. Woodcock 1 combines instruction with entertainment. In this companion to her volume on Scotland she has selected more than fifty places of interest scattered throughout England and has given her readers a bird's-eye view of the salient features of the history of each. Topographical and architectural details are strictly subordinated to elucidating the story. This is told admirably in a graphic and succinct narrative without unnecessary ornament. The author's interest is catholic, and she covers not only picturesque towns, such as Dover and Rye, Burford, Beverley, or York, but also castles, great houses, such as Knole and Hatfield, and ruins and prehistoric monuments, Kenilworth, Avebury and Stonehenge. Illustration is generous and excellent.

Lest a necessarily brief account of a book containing much, but not an overload of detail, should convey the impression that it is no more than an excellent 'gossiping guide', it may be pointed out that from the author's judicious selection of incident and the frequent juxtaposition of a number of distinct narratives of events drawn from identical periods in time, certain general trends in the history of the English people emerge. Such are, for example, the forces which welded the English, a people of so diverse an origin, into one, or the development in the relations of nobles and people and the cognate matter of the divergencies in form and character of the English township and the origin of these divergencies, some towns being appanages of a great house, such as Arundel and Warwick, others groupings of independent burgesses, arising with the early growth of trade, commerce and industry, as do the towns of the Cotswolds, or the Cinque Ports, which base their independence on the sea.

\section{(I) Wild Flowers in Britain}

By Robert Gathorne-Hardy.

Library.) Pp. $120+104$ plates. (London : B. T. Batsford, Ltd., 1938.) $8 s .6 d$. net.

(2) Everyman's Wild Flowers and Trees

Five Hundred of the British Wild Flowers, Trees, Shrubs, Grasses, and Ferns, described and illustrated, 384 in colour after Sowerby's "British Wild Flowers", and 120 from line-drawings by the Author. By Miles Hadfield. Pp. vii $+184+32$ plates. (London: J. M. Dent and Sons, Ltd., 1938.) 6s. net.

DRING the past few years there has been a spate of illustrated guides (not necessarily floras) to the plant life of Great Britain, especially the flowering plants. Some have been scarcely anything but vehicles for artists' impressions of attractive flowers, while others have proved very helpful not only to the amateur naturalist but also to the professional botanist. Now, therefore, in any new work on British wild flowers, we may feel justified in demanding some distinguishing features to warrant its publication.
(1) In Mr. Gathorne-Hardy's book we see such features. His ultimate aim is to instruct the amateur in the pleasures rather than the science of botany; and he would be a very hardened reader who does not become captivated by the author's pleasing style of description. He writes with such literary prowess and enthusiasm for his subject that the book makes good armchair reading. Thus it might fail in its main purpose, but it would be failure along the right lines, because the book is so beautifully illustrated. The photographs (many of them full-page) are some of the best we have seen. They have clearly been chosen with care from the work of the best living Nature photographers. Mr. John Nash's colour lithographs make an enchanting decoration to the whole work. Botanists and all other Nature lovers should welcome this book as a distinctive addition to a subject rather over-burdened in books.

(2) Mr. Miles Hadfield's book comes under a different category, since instead of putting the beauty of plant life in his book he puts the layman reader in the way of finding it in Nature for himself. The illustrations are useful for identification purposes only ; but that was obviously intended. The author's main aim is to extend the scope of the book to deal not only with herbs, but also with trees, shrubs and ferns by omitting the rarer species which only the skilled botanist is likely to recognize. The book opens with descriptions of classification and naming of plants, the structure of leaves and flowers, and means of identification. This is followed by illustrated descriptions of five hundred plants, grouped in families. A distinctive feature of the work is the consideration of the economic value of certain plants, garden relations and the meanings of the botanical names of plants. The author is to be congratulated on the production of a really useful book.

Clowes and Coleman's Quantitative Chemical Analysis : an Intermediate Text-Book. Edited and revised by Dr. D. Stockdale and J. Dexter. Fourteenth edition. Pp. xiv +617. (London: J. and A. Churchill, Ltd., 1938.) 188.

$\mathrm{IN}^{\mathrm{N}}$ this new edition of a well-known text-book the Iype has been completely reset and a large part of the text rewritten. Additions include accounts of the gravimetric and volumetric determination of aluminium and magnesium by 8-hydroxyquinoline, the colorimetric determination of aluminium, the use of the ehromate radical in the determination of barium, lead and sulphates, ferrous phenanthroline as an internal redox indicator, a brief introduction to the use of ceric sulphate, and the analysis of cupronickel by salicylaldoxime. The book thus includes some well-tried modern methods of analysis.

The sections on the analysis of water, foods, oils and fats, and gas analysis have been retained, since although these subjects are now best dealt with in special treatises, the processes included provide very useful introductions for the senior student, and also enable the teacher to set alternative exercises in special cases. The book is a thoroughly sound and accurate one and its continued popularity may be predicted. 